\title{
Metode Bimbingan Islami dalam Membentuk Akhlak Anak
}

\author{
${ }^{1}$ Muhibbah, ${ }^{2}$ Mawardi Siregar, ${ }^{3}$ Sabrida Ilyas \\ ${ }^{1}$ Jurusan Bimbingan dan Konseling Islam Fakultas Ushuluddin Adab dan Dakwah Institut Agama \\ Islam Negeri Langsa, Langsa \\ mailto:1mmuhibbah985@gmail.com,2sipirokpbujur76@gmail.com,3sabridailyas@gmail.com
}

$\begin{array}{ccc}\text { First received: } & \text { Revised: } & \text { Final Accepted: } \\ \text { 01 January } 2019 & \text { 02 February 2019 } & \text { 04 March } 2019\end{array}$

\begin{abstract}
The purpose of this study are: 1) To find out the Islamic guidance method in shaping children's morals at the AlHakim Paya Kulbi orphanage in Aceh Tamiang District, 2) to find out the implications of Islamic guidance in shaping children's morals at the Al-Hakim Paya Kulbi in Aceh Tamiang District. This type of research is field research. This is a qualitative descriptive study conducted directly on the object under study to obtain the data needed, meaning that the individual researchers talk and directly observe the people being examined using the method of observation, interviews and documentation. As the findings of the data obtained by researchers from primary data sources, namely orphanage children and administrators / educators of the orphanage. The results showed that the Islamic guidance method in shaping the character of children in the al-Hakim Paya Kulbi orphanage in Aceh Tamiang Regency is by using; 1) exemplary methods; 2) habituation methods; and 3) lecture methods. Furthermore, the implications of Islamic guidance in shaping the morals of children in the al-Hakim Paya Kulbi orphanage in Aceh Tamiang Regency are the formation of good behavior in the orphans, increased religious practices (praying, reciting in daily life, increasing the craft of orphans, and the formation of independence in the orphanage self orphanage.

Keyword: Islamic guidance, shaping children's morals
\end{abstract}

\begin{abstract}
Abstrak
Tujuan dari penelitian ini yaitu: 1) Untuk mengetahui metode bimbingan Islami dalam membentuk akhlak anak dipanti asuhan al-Hakim Paya Kulbi Kabupaten Aceh Tamiang, 2) untuk mengetahui implikasi bimbingan Islami dalam membentuk akhlak anak dipanti asuhan al-Hakim Paya Kulbi Kabupaten Aceh Tamiang. Jenis penelitian ini adalah penelitian lapangan (field research). Penelitian ini bersifat deskriptif kualitatif yang dilakukan langsung terhadap objek yang diteliti untuk mendapatkan data-data yang dibutuhkan, maksudnya peneliti secara individu berbicara dan mengamati secara langsung orang-orang yang sedang ditelitinya dengan menggunakan metode observasi, wawancara dan dokumentasi. Sebagaimana hasil temuan data diperoleh peneliti dari sumber data primer yaitu anak-anak panti dan pengurus/pendidik panti tersebut. Hasil penelitian menunjukkan bahwa metode bimbingan Islami dalam membentuk akhlak anak di panti asuhan al-Hakim Paya Kulbi Kabupaten Aceh Tamiang yaitu dengan menggunakan; 1) metode keteladanan; 2) metode pembiasaan, dan 3) metode ceramah. Selanjutnya, implikasi bimbingan Islami dalam membentuk akhlak anak di panti asuhan al-Hakim Paya Kulbi Kabupaten Aceh Tamiang yaitu terbentuknya perilaku baik pada diri anak panti, meningkatnya amalan agama (shalat, mengaji dalam sehari-hari, meningkatnya kerajinan anak panti, dan terbentuknya kemandirian pada diri anak panti.

Kata Kunci: Bimbingan Islami, Pembentukan akhlak
\end{abstract}

\section{A. Pendahuluan}

Dalam menumbuhkan akhlak baik seperti kejujuran, adil dan sebagainya, seorang anak harus mendapatkan contoh dari orangorang di sekitarnya. Apabila si anak biasa menerima perlakuan adil dan dibiasakan pula berbuat adil, maka akan tertanamlah rasa keadilan itu kepada jiwanya dan menjadi salah satu unsur dari kepribadiannya. ${ }^{1}$ Adapun ciri-ciri orang yang memiliki akhlak yang baik, para ulama juga menyebutkan yakni: pemalu, jarang menyakiti, suka berbuat kebaikan, jujur, sedikit bicara, banyak beramal, sedikit

1 Zakiah Darajat, Kesehatan Mental(Jakarta: Toko Gunung Agung, 1995), h. 128. 
kesalahan, tidak banyak menonjolkan diri, berbakti, menyambung kekerabatan, tenang, sabar, suka berterima kasih, ridha, santun, menepati janji, dan menjaga harga diri. Tidak suka melaknat, mencela, mengadu domba ataupun menggunjing. Tidak gegabah, dengki, bakhil, dan tidakpula iri hati. Berwajah gembira dan murah senyum, mencintai karena Allah, membenci karena Allah, ridha karena Allah dan marah karena Allah. Semua itu termasuk definisi orang yang memiliki akhlak yang mulia dilihat dari sebagian sifatsifatnya. ${ }^{2}$

Dalam hal membentuk akhlak yang mulia, pada keluarga kita memerlukan bimbingan, bimbingan itu pada dasarnya merupakan suatu proses usaha pemberian bantuan atau pertolongan kepada orang lain (siapa saja) dalam segala usia, yang dilakukan secara terus menerus (berkesinambungan) yang mana orang itu mengalami kesulitan atau hambatan dalam hidupnya (secara psikis), sehingga dengan bantuan atau pertolongan itu orang yang diberikan bantuan (terbimbing) dapat mengarahkan dirinya, mampu menerima dirinya, dapat mengembangkan potensinya untuk kebahagiaan dan kemanfaatan dirinya dan lingkungan masyarakatnya.

${ }^{2}$ Syaikh Abu Bakar Jabir Al Jazairy, Minhajul Muslim (Pedoman Hidup Harian Seorang Muslim)(Jakarta: Ummul Qura, 2014), h. 307-309.
Selanjutnya bimbingan dan agama merupakan satu kesatuan yang tidak bisa dilepaskan, untuk itu bimbingan keagamaan mengandung pengertian suatu proses pemberian bantuan kepada individu yang dilakukan secara terus menerus atau berkesinambungan berdasarkan landasan Al-Qur'an dan Al-Hadits sehingga individu mampu menyadari segala perilakunya yang salah dan kembali ke perilaku sesuai dengan syariat Islam. Bimbingan keagamaan diberikan atas dasar kewajiban yang harus dilakukan setiap manusia sebagai bentuk mengingatkan dan menyerukan kebaikan.

Akhlak maupun moral harus diajarkan kepada anak-anak dan harus disadarkan pula tentang baik dan buruk. Di Panti Asuhan AlHakim menampung anak yatim, piatu, maupun yatim piatu dan maupun yang ditinggal orang tua dan ada juga yang orang tuanya tidak mampu untuk menafkahi anaknya (ekonominya lemah). Mereka yang sudah berada dalam panti dididik sebaik mungkin oleh pembimbing atau pengasuh atau pihak-pihak yang bersangkutan sehingga mereka dapat menjadi anak yang mandiri dan berakhlak baik. Pembimbing atau pengasuh juga memberikan contoh tauladan yang baik, pembiasaan secara terusmenerus. Namun yang tampak di panti tersebut, masih banyak anakanak panti yang tidak mengamalkan semua yang telah diajarkan oleh 
pengasuh di panti. Anak-anak tersebut juga masih kurang dalam mengindahkan akhlak dalam kehidupan sehari-hari baik itu saat bermain di luar panti maupun saat berada di panti. Seperti, anak-anak tersebut masih mau bolos-bolos sekolah padahal pihak panti telah membiayai sekolah mereka dan juga saat di panti mereka (anak laki-laki) berkelahi sesama anak panti. Hal yang demikian sering terjadi meski pengasuh di panti selalu menasehati anak-anak tersebut.

Di Panti Asuhan al-Hakim Paya Kulbi Kabupaten Aceh Tamiang ini anak-anak dididik sebaik mungkin oleh pembimbing agama agar menjadi anak yang mandiri dan berakhlak baik. Namun mengurus anak-anak dan membentuknya langsung menjadi anak yang memiliki akhlak mulia bukanlah hal yang mudah, memerlukan proses terutama bimbingan.

Berdasarkan latar belakang masalah tersebut diatas, penulis tertarik untuk mengkajinya dalam suatu penelitian yang diberi judul: "Metode Bimbingan Islami Dalam Membentuk Akhlak Anak di Panti Asuhan Al-Hakim Paya Kulbi Kabupaten Aceh Tamiang".

\section{B. Metodologi}

Jenis penelitian ini merupakan penelitian lapangan (field research). Pengumpulan data yang dilakukan dalam penelitian ini ada tiga cara yaitu: 1) observasi (pengamatan), 2) interview (wawancara) dan dokumentasi.

\section{Pembahasan}

1. Metode Bimbingan Islami dalam Membentuk Akhlak Anak di Panti Asuhan Al-Hakim Paya Kulbi Kabupaten Aceh Tamiang

Berdasarkan penjelasan sebelumnya, yang menjadi metode bimbingan Islami dalam pembentukan akhlak anak di Panti Asuhan Al-Hakim Paya Kulbi Kabupaten Aceh Tamiang antara lain:

\section{Metode Keteladanan}

Berdasarkan hasil observasi peneliti dan wawancara dengan Novalita sebagai pengurus panti Asuhan Al-Hakim Paya Kulbi, keteladanan yang ada di panti yaitu: "Saya memberikan contoh yang baik untuk anak-anak panti ini. Seperti bertutur kata lembut dan sopan kepada mereka, bersikap bijaksana, bersikap baik (ramah, penuh kasih sayang, jujur) dan tegas dalam mengambi sikap. Ini semua kita contohkan kepada anak panti agar tertanam dalam diri mereka akhlak yang mulia."3

Atas pernyataan di atas, dapat dipahami bahwa dalam membentuk akhlak anak panti tersebut yaitu dengan memberikan contoh yang baik. Jadi dengan memberikan contoh yang baik anak akan tertanam pula contoh tauladan tersebut sebagaimana berbicara

${ }^{3}$ Novalita, selaku kepala Yayasan Panti Asuhan Al-Hakim Paya Kulbi, wawancara tanggal 8 Agustus 2019 di panti Asuhan Al-Hakim Paya Kulbi. 
dengan sopan santun, jujur dan juga bersikap baik yang lainnya.

Hasil observasi peneliti dan wawancara dengan Salawati, salah satu pengurus Panti Asuhan AlHakim Paya Kulbi, menyatakan bahwa:

"Memberi contoh tauladan baik itu berupa tingkah laku maupun lisan. Dengan memberi contoh yang baik, maka akan menghasilkan anak yang punya akhlak maupun kepribadian yang baik. Kami berupaya untuk menjadi contoh tauladan seperti contoh mengambil sampah yang berserakan di halaman, sebelum kami memerintahkan dan menyuruh anak-anak panti, maka terlebih dahulu kami memberikan contoh untuk mengambil sampah tersebut. Kemudian dalam bergaul dengan sesama anak panti, kami di sini mencontohkan bagaimana bersikap yang baik kepada anak begitu juga anak kepada pengurus, jadi kami sebagai pengurus di sini yang mengawali dari diri sendiri bersikap yang baik terhadap anak-anak baik dalam berbicara maupun bertindak, dengan begitu anak-anak akan mencontoh pengurusnya dalam hal tersebut." ${ }^{4}$

Berdasarkan pernyataan di atas, dapat dipahami bahwa memberikan contoh yang baik

${ }^{4}$ Salawati, selaku pengurus Panti Asuhan Al-Hakim Paya Kulbi, wawancara tanggal 8 Agustus 2019 di panti Asuhan AlHakim Paya Kulbi. adalah salah satu sara yang tepat dalam membentuk akhlak anak panti. Misalnya saja seperti mengutip sampah yag berserakan di halaman dan lainnya.

2. Pembiasaan

Hasil observasi peneliti dan wawancara dengan Novalita sebagai pengurus, metode pembiasaan yang ada di panti yaitu:

"Pembiasaan yang meliputi kegiatan di panti ya kegiatankegiatan keagamaan seperti kegiatan ibadah berupa membaca Al-Qur'an yang rutin dilaksanakan setiap hari jum'at dengan saya, shalat dhuha (tapi tidak rutin, biasanya hari minggu), shalat dhuhur berjama'ah, sopan santun, dan juga menerapkan konsep 35 yaitu senyum, sapa dan salim. Kebiasaan ini kalau tidak dibiasakan mulai dini, maka kebiasaan-kebiasaan seperti ini tidak pernah terlaksana hingga dewasa nanti." ${ }^{5}$

Atas pernyataan di atas, dapat dipahami bahwa metode lainnya dalam membentuk akhlak anak di panti yaitu dengan pembiasaan. Pembiasaan yang dimaksud yaitu berupa ibadah rutin seperti membaca Al-Qur'an, shalat berjamaah dan menerapkan konsep 3S (Senyum, Sapa, dan Salim).

"Kegiatan rutin yang dilakukan anak-anak di panti seperti dari pagi mereka pergi ke sekolah,

${ }^{5}$ Novalita, selaku kepala Yayasan Panti..., di panti Asuhan Al-Hakim Paya Kulbi. 
pulang dari sekolah mereka istirahat dan pada waktu sore hari mereka bertani. Ya seperti menanam jagung dibelakang panti, menanam ubi juga, malamnya mereka mengaji. Besar pengaruhnya untuk mereka. Mereka sekarang sudah mulai terbiasa dengan pola hidup yang kita tekankan di panti. Anak-anak panti menjalankan shalat 5 waktu di panti, jika masuk waktu makan mereka juga sudah biasa dengan memasak (ada jatah piketnya) dan membersihkan perkarangan panti setelah bertani pada sore harinya. Yang pada intinya mereka saat ini sudah menjadi lebih baik. Baik itu dari segi ibadah maupun dari segi akhlak."6

Tambah Novalita, "Bimbingan seperti mengatur pola hidup mereka agar menjadi lebih disiplin, pola tidur mereka juga dan beribadah mereka pun kita tekankan. Supaya hidup mereka dewasa kelak akan lebih baik, disiplin dan terbiasa dengan pola hidup yang kita tekankan dari sekarang ini."

Atas pernyataan di atas, dapat dipahami bahwa cara lainnya yaitu dengan kegiatan rutin dari mulai berangkat sekolah hingga wakunya istirahat dan adanya pula kegiatan bertani seperti menanam jagung di belakang panti, begitu pula dengan kegiatan lainnya seperti

6 Nova..., wawancara tanggal 8 Agustus 2019 di panti Asuhan Al-Hakim Paya Kulbi. adanya jatah piket masing-masing anak, hal tersebut juga dapat membentuk kedisipinan anak dan akan membentuk akhlaknya pula.

Begitu juga pernyataan dari Salawati, pengurus Panti Asuhan Al-Hakim Paya Kulbi:

“Menegakkan kedisiplinan juga salah satu cara untuk dapat membentuk akhlak anak. Upaya yang harus segera dilakukan oleh pihak panti dalam upaya mendisiplinkan anak-anak, sehingga mereka memiliki perilaku yang baik dan berprestasi. Ini memang usaha yang tidak mudah, selain juga membutuhkan waktu yang tidak pendek. Membentuk pribadi anak agar dewasa dalam setiap perilaku dan apalagi selalu cenderung pada pencapaian prestasi membutuhkan kesungguhan upaya, baik sistemik maupun teladan nyata dari lingkungan panti ini."7

Pernyataan di atas juga menjelaskan tentang kedisiplinan sebagai salah satu cara dalam membentuk akhlak anak panti sengaja dibentuk agar agar memiliki akhlak yang baik dan berprestasi.

Berikut juga pernyataan dari salah satu pengurus panti yang menyatakan bahwa:

"Kedisplinan anak-anak panti di sini sangat kami terapkan. Karena dengan disiplin anak-

7 Salawati, pengurus panti..., di panti Asuhan Al-Hakim Paya Kulbi. 
anak tersebut nantinya akan menjadi pribadi yang lebih baik lagi dan teratur hidupnya. Contohnya kedisplinan yang kami terapkan di panti ini yaitu seperti shalat tepat waktu dan juga piket dengan tepat waktu juga." ${ }^{8}$

Jadi, atas dasar penjelasan di atas, dapat dipahami bahwa pembiasaan menjadi salah satu metode yang digunakan dalam memberikan bimbingan pada anakanak panti tersebut. Pembiasaan tersebut seperti membiasakan anakanak menjalankan shalat berjamaah di panti, menerapkan konsep 3S yaitu senyum, sapa dan salim, membiasakan dengan pola hidup yang baik, shalat dan piket dengan tepat waktu dan disiplin (baik untuk pribadi maupun untuk bersama).

3. Metode ceramah

Hasil observasi peneliti dan wawancara dengan Ustad Abdul Latif selaku tenaga pengajar anak Panti Asuhan Al-Hakim Paya Kulbi, metode ceramah yang ada di panti yaitu:

“Perihal yang saya ajarkan yaitu tentang adab dan perilaku yang utama. Biasanya kalau hari jum'at itu saya bercemarah dengan tema mencontoh keteladanan Rasulullah. Banyak teladan Rasul yang bisa diceritakan agar anak-anak tau dan mengikuti teladan-teladan

${ }^{8}$ Fatimah, salah satu pengurus panti Asuhan Al-Hakim Paya Kulbi, wawancara tanggal 10 Agustus 2019 di panti Asuhan Al-Hakim Paya Kulbi.
Rasul dalam sehari-harinya. Saya juga mengajarkan anakanak ilmu agama seperti menceritakan sejarah dan perkembangan Islam, dan menceritakan kisah-kisah Nabinabi dan Rasul, supaya mereka bisa meneladaninya. Dan sekarang saja sudah tampak anak-anak terlihat perubahan yang sangat baik sebagaimana keteladanan Rasul yang sering saya ceritakan seperti disiplin dalam menjalankan shalat 5 waktu maksudnya tepat waktu. $" 9$

Atas pernyataan di atas dapat dipahami bahwa salah seorang pengajar membentuk akhlak anak panti dengan selalu menceritakan sejarah-sejarah nabi dan juga akhlak-akhlak terpuji nabi. Sehingga hal tersebut dilakukan berulang-ulang agar anak panti dapat mengingatnya dan membiasakannya.

Hasil observasi peneliti dan wawancara dengan Tgk. Jamal, selaku tenaga pengajar anak Panti Asuhan Al-Hakim Paya Kulbi, menjelaskan bahwa

"Setiap hari senin sampai kamis saya mengajar anak-anak panti, dalam waktu pengajian itu berlangsung, 4 kali dalam seminggu saya mengajarkan ilmu agama anak-anak dengan metode ceramah. Tema yang biasa diajarkan ya biasa

${ }^{9}$ Ustad Abdul Latif, pengajar di panti Asuhan Al-Hakim Paya Kulbi, wawancara tanggal 8 Agustus 2019 di rumahnya. 
termasuk dalam keseharian anak-anak seperti berperilaku sopan santun terhadap orang tua dan saling mengahargai sesama teman. Maksudnya dengan memberi pehamanan perihal perilaku dalam seharihari seperti itu, jadi mereka merealisasikannya dalan kehidupan mereka dan juga saya mengajarkan penjelaskanpenjelasan apa-apa yang menjadi perintah Allah dan apaapa yang menjadi laranganNya, juga mengajarkan mereka perihal wajib, haram, sunnah dan makruh dan yang terpenting juga mengajarkan mereka tajwid supaya bacaan shalat mereka benar." 10

Pernyataan di atas juga menjelaskan tentang pembentukan aklah anak panti namun dengan berceramah dengan tema berperilaku sopan santun dengan orang tu dan saling menghargai dengan sesama teman.

Berdasarkan hasil observasi peneliti dan wawancara dengan pegurus dan pengajar panti, dapat disimpulkan bahwa metode bimbingan Islami yang digunakan untuk pembentukan akhlak anak panti ada 3 (tiga) yaitu 1) metode keteladanan. Seperti bertutur kata lembut dan sopan, bersikap bijaksana, bersikap baik dan tegas dalam mengambi sikap, mencontohkan membuang sampah pada tempatnya dan beradab dalam

${ }^{10}$ Tgk. Jamal, pengajar di panti Asuhan Al-Hakim Paya Kulbi, wawancara tanggal 8 Agustus 2019 di rumahnya. sehari-hari. 2) Pembiasaan. Seperti membiasakan anak-anak menjalankan shalat berjamaah di panti, menerapkan konsep 35 yaitu senyum, sapa dan salim, membiasakan dengan pola hidup yang baik, shalat dan piket dengan tepat waktu dan disiplin (baik untuk pribadi maupun untuk bersama). 3) Ceramah. Seperti memberi pehamanan mereka dengan menjelaskan apa-apa yang menjadi perintah Allah dan apa-apa yang menjadi larangan-Nya, juga mengajarkan mereka perihal halal haram.

2. Implikasi Bimbingan Islami dalam Membentuk Akhlak Anak di Panti Asuhan Al-Hakim Paya Kulbi Kabupaten Aceh Tamiang

Dalam pembentukan akhlak anak, yang terpenting dalam bimbingan yang diberikan yaitu akibat langsung yang didapat dari upaya tersebut maupun perubahan yang tampak dari bimbingan yang telah diberikan tersebut, di antaranya:

1. Terbentuknya perilaku baik pada diri anak panti

Hasil wawancara dengan Fadhuli, anak panti:

"Banyak hal yang saya dapatkan selama tinggal di panti ini. Dan sekarang semakin hari saya semakin bertambah pemahanan saya soal mana yang baik dan buruk. Seperti pemahaman saya tentang budi pekerti dan akhlak yang baik. 
Ya pastinya saya akan menghindari perilaku buruk."11

Atas dasar penjelasan di atas, dapat dipahami bahwa dengan adanya metode bimbingan yang telah dilakukan maka dapat membentuknya perilaku baik buruk dalam diri anak panti. Perilaku tentang budi pekerti dan akhlak yang baik.

2. Meningkatnya amalan agama (shalat dan mengaji) dalam sehari-hari

Hasil wawancara Novalita, sebagai berikut:

"Sangat alhamdulillah sekali, anak-anak panti sudah lebih baik salah satunya dari segi keagamaannya. Contohnya saja seperti anak-anak yang sudah lebih rajin mengikuti pengajian tiap malamnya, shalat berjamaah dan berlaku lebih sopan dengan sesama di panti."12

Atas penjelasan di atas, dapat dipahami bahwa adanya peningkatan nilai-nilai keagamaan dalam diri anak panti, hal tersebut dapat dilihat dari rajinnya anakanak mengikuti pengajian dan mengikuti shalat berjamaah dan juga saling menghargai dengan sesama.
3. Meningkatnya kerajinan anak-panti

\footnotetext{
${ }^{11}$ Fadhuli, anak panti Asuhan Al-
} Hakim Paya Kulbi, wawancara tanggal 10 Agustus 2019 di panti Asuhan Al-Hakim Paya Kulbi.

${ }^{12}$ Novalita, selaku kepala Yayasan Panti..., di panti Asuhan Al-Hakim Paya Kulbi.
Hasil wawancara dengan Ulin, salah satu anak panti Asuhan Al-Hakim Paya Kulbi, sebagai berikut:

"Ibu-ibu pengasuh di panti ini memang baik-baik, kadang kami aja yang nakalnya luar biasa. Selalu kami dinasehati dengan baik-baik jadi kami lama kelamaan berubah, sikap kami pun jadi lebih baik. baik itu dengan pengasuh di sini maupun dengan sesama anakanak panti di sini lah. Kami pun sudah tidak malas lagi mengaji, kalau dulu memang malas untuk ikut mengaji. Lagipula yang ngajar ngajinya juga baik dan akrab dengan anak-anak panti di sini, jadi kami terkesan."13

Atas dasar penjelasan di atas, dapat dipahami bahwa adanya perubahan perilaku yang tambak lebih baik pada anak tersebut karena pengurus panti yang selalu menasehati mereka dengan terus menerus dan juga dengan bahasa yang lembut.

4. Terbentuknya kemandirian pada diri anak panti

Hasil wawancara dengan Ilham, salah satu anak panti Asuhan Al-Hakim Paya Kulbi, sebagai berikut:

"Sekarang ini hidup saya lebih terarah, karena bimbingan yang telah diberikan oleh pengurus di

13 Ulin, anak panti Asuhan AlHakim Paya Kulbi, wawancara tanggal 9 Agustus 2019 di panti Asuhan Al-Hakim Paya Kulbi. 
sini sangat teratur. Baik itu kedisiplinan saya maupun kemandirian saya. Kalau dulu saya tidak bisa mandiri seperti apa saja yang saya perlukan saya memintanya sama orang tua padahal itu hal sepele. Tapi sekarang saya sudah lebih mandiri. Semua saya lakukan sendiri seperti menyiapkan baju untuk sekolah, saya juga membersihkan kamar tidur di panti sendiri, dan banyak lah yang lainnya." 14

Berdasarkan penjelasan di atas, bahwasanya anak-anak panti sudah terbentuknya kemandirian pada diri anak panti dan hal tersebut dapat dilihat dari mereka dapat mempersiapkan perlengkapan sekolah sendiri tanpa diurus oleh pengurus maupun oorang tuanya lagi.

Begitu pula penjelasan dari Amar, salah satu anak panti yang sudah remaja pada panti Asuhan AlHakim Paya Kulbi, sebagai berikut:

"Saya merasa hidup saya sudah lebih baik, yang dahulunya saya sangat teledor dan hidup tidak ada aturannya tapi sekarang hidup saya sudah lebih terarah seperti, tidur dan makan saya sekarang sudah teratur, setiap harinya membersihkan perkarangan panti juga dan saya sudah

${ }^{14}$ Ilham, anak panti Asuhan AlHakim Paya Kulbi, wawancara tanggal 9 Agustus 2019 di panti Asuhan Al-Hakim Paya Kulbi. menjadi lebih tau mana yang baik dan mana yang buruk, pokoknya lebih terarah lah, dan banyak ilmu-ilmu agama yang saya dapat dari panti ini." 15

Atas dasar penjelasan di atas, dapat dipahami bahwa anak-anak panti sudah terbentuknya pola hidup sehat, hal tersebut dapat terlihat dari pola hidup mereka sehari-hari.

Berdasarkan metode yang telah digunakan oleh pengurus dan pengajar di panti Asuhan Al-Hakim Paya Kulbi yang dianggap efektif dalam pembentukan akhlak anak panti. Maka implikasi dari metode tersebut yang telah terbentuk antara lain terbentuknya perilaku dan kebiasaan baik pada anak panti, meningkatnya amalan agama (shalat dan mengaji) dalam sehari-hari, meningkatnya kerajinan anak panti dan terbentuknya kemandirian pada diri anak panti. Adapun menurut Sjarkawi dalam buku Pembentukan Kepribadian Anak menjelaskan bahwa pembentukan akhlak secara mendasar dalam mewujudkan nilainilai positif sebagaimana yang diajarkan dalam pendidikan akhlak tersebut dan juga sebaliknya, menghindari atau menolak diri dari seluruh nilai positif akan terwujudnya perilaku negatif. Namun demikian, yang perlu diperhatikan dalam penelitian ini adalah bagaimana metode yang

${ }^{15}$ Amar, anak panti Asuhan AlHakim Paya Kulbi, wawancara tanggal 10 Agustus 2019 di panti Asuhan Al-Hakim Paya Kulbi. 
digunakan tersebut sangat efektif dapat menimbulkan implikasi atau efektifitas yang positif bagi diri anak panti tersebut. ${ }^{16}$

\section{Kesimpulan}

Metode bimbingan Islami dalam membentuk akhlak anak di panti asuhan al-Hakim Paya Kulbi Kabupaten Aceh Tamiang yaitu dengan menggunakan 1) metode keteladanan seperti bertutur kata lembut dan sopan, bersikap bijaksana, bersikap baik dan tegas dalam mengambil sikap, mencontohkan membuang sampah pada tempatnya; 2) metode pembiasaan seperti membiasakan anak-anak menjalankan shalat berjamaah di panti, menerapkan konsep 35 yaitu senyum, sapa dan salim, membiasakan dengan pola hidup yang baik, shalat dan piket dengan tepat waktu dan disiplin; dan 3) metode ceramah seperti memberi pemahaman mereka dengan menjelaskan apa-apa yang menjadi perintah Allah dan apa-apa yang menjadi larangan-Nya. Selanjutnya, implikasi bimbingan Islami dalam membentuk akhlak anak di panti asuhan al-Hakim Paya Kulbi Kabupaten Aceh Tamiang yaitu terbentuknya perilaku baik pada diri anak panti, meningkatnya amalan agama (shalat, mengaji dalam sehari-hari, meningkatnya kerajinan anak panti, dan terbentuknya kemandirian pada diri anak panti.

\begin{tabular}{llll}
\hline \multicolumn{2}{c}{ Sjarkawi, Pembentukan } \\
Kepribadian Anak, (Jakarta: PT Bumi \\
Aksara, 2008), h. 35
\end{tabular}

\section{DAFTAR PUSTAKA}

Abdulkadir, A. (2004). Hukum dan Penelitian Hukum, Bandung: Citra Aditya Bakti.

Abuddin, N. (2008) Akhlak Tasawuf, Jakarta: PT. RajaGrafindo Persada.

Amin., \& Munir, S. (2010) Bimbingan dan Konseling Islam, Jakarta: Amzah.

Darajat., \& Zakiah. (1995). Kesehatan Mental, Jakarta: Toko Gunung Agung.

Departemen Agama RI. (2007). AlQur'an dan Terjemahnya, Solo: PT Tiga Serangkai Pustaka Mandiri.

Jafasat, Dakwah Media Aktualisasi Syariat Islam, Banda Aceh: Dinas Syariat Islam Aceh, 2011

Jazairy. A., \& Jabir. S, A, B. (2014) Minhajul Muslim (Pedoman Hidup Harian Seorang Muslim, Jakarta: Ummul Qura

Prayitno. (2009). Dasar-Dasar Bimbingan dan Konseling, Jakarta: PT Rineka Cipta.

Sjarkawi. (2008). Pembentukan Kepribadian Anak, Jakarta: PT Bumi Aksara.

Usman, H. (2000) Metodelogi Penelitian Sosial, Jakarta: Bumi Aksara. 